\title{
Mechanistic modeling of UV and mild-heat synergistic effect on solar water disinfection
}

\author{
María Castro-Alférez ${ }^{\text {a,b }}$, María Inmaculada Polo-López ${ }^{\mathrm{a}, \mathrm{b}}$, Javier Marugán ${ }^{\mathrm{c}}$, Pilar Fernández-Ibáñez ${ }^{\text {a,d,* }}$ \\ a Plataforma Solar de Almería - CIEMAT, P.O. Box 22, 04200 Tabernas (Almería), Spain \\ ${ }^{\mathrm{b}}$ CIESOL, Joint Centre of the University of Almería-CIEMAT, 04120 Almería, Spain \\ ${ }^{\mathrm{c}}$ Department of Chemical and Environmental Technology, ESCET, Universidad Rey Juan Carlos, C/Tulipán s/n, 28933 Móstoles (Madrid), Spain \\ ${ }^{\mathrm{d}}$ Nanotechnology and Integrated BioEngineering Centre, School of Engineering, University of Ulster, Newtownabbey, Northern Ireland BT37 0QB, United Kingdom
}

\section{H I G H L I G H T S}

- Bacterial dark thermal inactivation was modeled in the range of $10-$ $55^{\circ} \mathrm{C}$.

- Synergy between UV and mild-heat in solar disinfection was proven.

- Mechanistic model of SODIS based on UV and temperature synergy was developed.

- Model predictions were validated with experiments at variable temperature.

\section{A R T I C L E I N F O}

\section{Article history:}

Received 15 October 2016

Received in revised form 8 January 2017

Accepted 9 January 2017

Available online 19 January 2017

\section{Keywords:}

E. coli

SODIS

Model

Synergy

Thermal effect
G R A P H I C A L A B S T R A C T

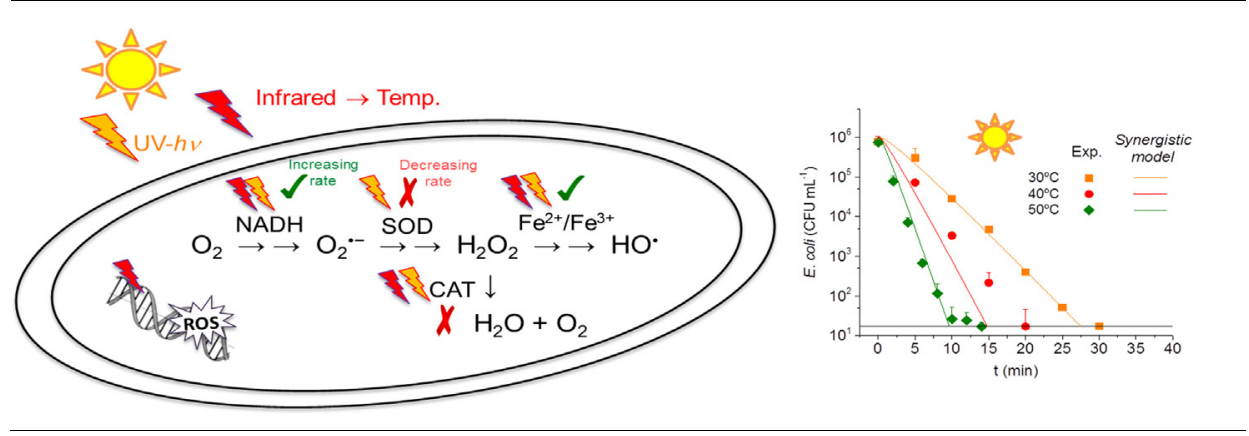

\begin{abstract}
A B S T R A C T
A mechanistic model of inactivation of Escherichia coli by the action of solar UV radiation and simultaneous solar mild-heat occurring during solar water disinfection (SODIS) is proposed. Bacterial killing during solar exposure of transparent bottles full of contaminated water for at least $6 \mathrm{~h}$ in full sunshine is attributed to the combined effect of, i) the UV photons absorbed by bacteria and producing intracellular reactive oxygen species (ROS) that induce oxidative damages, and ii) a mild increase of water temperature (commonly between $25^{\circ} \mathrm{C}$ and $50{ }^{\circ} \mathrm{C}$ ) that accelerates the bacterial inactivation process. This work proposes a model based on a simplified approach of the kinetic reactions that explain the synergy between UV radiation and temperature to successfully reproduce SODIS experimental results. The main factors considered in this model are (i) the photo-induced formation of intracellular ROS from oxygen and photo-sensitizers that takes into account the internal thermal and photo-Fenton reactions; (ii) the thermal and photo-inactivation of catalase and superoxide dismutase and (iii) the internal damages due to the action of these oxidative and thermal effects. The new model has been demonstrated to reproduce the time-profile of $E$. coli concentration in clear water at different temperatures $\left(10-55^{\circ} \mathrm{C}\right)$ and under different solar irradiances ( $30-50 \mathrm{~W} \mathrm{~m}^{-2} \mathrm{UV}$ ). The excellent fitting between model and experimental results suggests that the mechanistic model considering the synergistic effect between UV radiation and temperature is a realistic approach for the simulation of solar water disinfection process.
\end{abstract}

(c) 2017 Elsevier B.V. All rights reserved.

\footnotetext{
* Corresponding author at: Nanotechnology and Integrated BioEngineering Centre, School of Engineering, University of Ulster, Newtownabbey, Northern Ireland BT37 0QB, United Kingdom.

E-mail addresses: pilar.fernandez@psa.es, p.fernandez@ulster.ac.uk (P. Fernández-Ibáñez).
}

\section{Introduction}

It is widely known the effective application of solar radiation for killing microorganisms. This bactericidal characteristic has been 


\section{Nomenclature}

\begin{tabular}{|c|c|}
\hline SODIS & solar disinfection \\
\hline ROS & reactive oxygen species \\
\hline CAT & catalase \\
\hline SOD & superoxide dismutase \\
\hline CFU & colony forming units \\
\hline OM & organic matter \\
\hline B & bacteria \\
\hline NADH & nicotinamide adenine dinucleotide \\
\hline$e^{\mathrm{a}}$, LVRPA & $\begin{array}{l}\text { local volumetric rate of photon absorption } \\
\left.\text { (Einstein } \mathrm{cm}^{-3} \mathrm{~s}^{-1}\right)\end{array}$ \\
\hline$\kappa$ & absorption coefficient $\left(\mathrm{cm}^{-1}\right)$ \\
\hline$\kappa^{*}$ & specific absorption coefficient $\left(\mathrm{M}^{-1} \mathrm{~cm}^{-1}\right)$ \\
\hline G & incident radiation (Einstein $\mathrm{cm}^{-2} \mathrm{~s}^{-1}$ ) \\
\hline$\lambda$ & wavelength (nm) \\
\hline$r$ & $\begin{array}{l}\text { reaction rate }\left(\mathrm{M} \mathrm{s}^{-1} \text { for intracellular species or }\right. \\
\text { CFU } \mathrm{mL}^{-1} \mathrm{~s}^{-1} \text { for bacteria) }\end{array}$ \\
\hline$k$ & $\begin{array}{l}\text { kinetic constant (units depend on the specific reaction } \\
\text { step) }\end{array}$ \\
\hline$\delta_{1}$ & kinetic parameter $\left(\mathrm{M} \mathrm{s}^{-1}\right)$ \\
\hline$\delta_{2}$ & kinetic parameter $\left(\mathrm{M} \mathrm{cm}^{3}\right.$ Einstein $\left.^{-1}\right)$ \\
\hline$\delta_{3}$ & kinetic parameter $\left(\mathrm{s}^{-1}\right)$ \\
\hline$t$ & time $(s)$ \\
\hline
\end{tabular}

$\mathrm{T} \quad$ temperature $(\mathrm{K})$

A pre-exponential factor (units depend on the specific reaction step)

Ea activation energy $\left(\mathrm{J} \mathrm{mol}^{-1}\right)$

$R \quad$ ideal gas constant $\left(\mathrm{J} \mathrm{K}^{-1} \mathrm{~mol}^{-1}\right)$

NRMSLE normalized root mean squared logarithmic error (\%)

$\begin{array}{ll}\text { Subscripts } \\ 0 & \text { indicates initial condition } \\ \mathrm{V} & \text { relative to viable bacteria } \\ \mathrm{i} & \text { relative to inactive bacteria } \\ \text { red } & \text { reduced } \\ \text { ox } & \text { oxidized }\end{array}$

Special symbols

[ ] concentration of intracellular chemical species (M) or concentration of bacteria in the bulk ( $\mathrm{CFU} \mathrm{mL} \mathrm{mL}^{-1}$ ) indicates an averaged valued in the UVA range $(300-400 \mathrm{~nm})$ used for water disinfection since 1980 [1], which was defined as solar water disinfection, or by its acronym SODIS. This is a household technique, appropriate as intervention measure for areas where access to safe drinking water is very difficult, or for emergency situations as a short-term, point-of-use water treatment after natural or man-made disaster situations, as it was recognized by the WHO and UNICEF since 2005 [2]. The main objective of SODIS is the reduction of the water pathogen load that is achieved due to the combined action of mild-heat and UV-photons over microorganisms, which is recognized as a synergistic effect between both factors [2]. UVB part of the spectrum is directly absorbed by cells causing damages on DNA chain that may propitiate the interruption of DNA replication or the generation of mutations [3]. UVA also affects to the microbial reproduction by an indirect route. UVA light is absorbed by some endogenous chromophores that alter the electron transport chain and induce the formation of reactive oxygen species (ROS) [4]. These species induce oxidative stress that may modify the cellular functionality by the formation of pyrimidine dimers, peroxidation of proteins and lipids, losses in membrane permeability, or DNA rupture generating single strand breaks (SSBs) [5]. In addition, UV interfere in the activity of some protective enzymes as catalase (CAT) or superoxide dismutase (SOD) that reduce or inhibit the action of ROS to prevent oxidative damages [6].

Several factors affect the efficiency of SODIS, lengthening or shortening the required sunlight exposure time to achieve a certain log-reduction. Moreover, a 4-log reduction is required by the WHO harmonized testing protocol for drinking water disinfection at household level as a highly protective level measure for bacteria [7]. Solar irradiance and energy dose, water temperature during treatment, water turbidity, dissolved oxygen and dissolved organic matter in the contaminated water, and nature of the microorganisms are the most important factors that alter disinfection efficiency [8-10]. Regarding the temperature effect, Solic et al. studied the separated and combined effect of solar radiation and temperature on the survival of faecal coliforms in seawater [11]. In the radiation:temperature combined experiments, the temperature ranged $14.5-24.9^{\circ} \mathrm{C}$ and solar irradiance ranged $510-830 \mathrm{~W} \mathrm{~m}^{-2}$ (spectral range was not mentioned). The authors performed a statistical analysis based on the comparison of the coefficients of partial correlation of radiation and temperature respectively and an ANOVA analysis to determine the importance of each effect. It was concluded that the effect of solar radiation is much important than temperature and the effects of temperature and solar radiation are not simply additive but are synergistic in their effect [11]. Later, Wegelin et al. found that water temperature between 20 and $40{ }^{\circ} \mathrm{C}$ do not affect the inactivation of bacteria by UVA and visible light radiation. These authors observed that above $50{ }^{\circ} \mathrm{C}$ the fluences required for $\mathrm{E}$. coli inactivation were more than three times smaller compared to lower water temperatures [12]. In line with this, Berney et al. studied the thermal effect on E. coli in dark and observed at slight rate of inactivation even at $48{ }^{\circ} \mathrm{C}$ [13]. Due to this strong synergy, a number of enhancement methods have been proposed based upon water thermal increase for SODIS acceleration. Some techniques used were: (i) black paint over some sections of the bottles; (ii) absorptive materials for SODIS containers; (iii) recirculation of water over a black surface in an enclosed container transparent to UVA light; (iv) solar collectors or solar reflectors to increment solar income in the container [2].

The beneficial effect of higher temperatures for solar disinfection has been widely demonstrated experimentally. Nevertheless, the increase in the disinfection efficiency was directly attributed to a synergy between temperature and radiation, but not any rigorous comparison of the single effects addition was performed. It was not until 1998, when McGuigan et al. reported the evidence of this synergy developing empirical models that predicted the inactivation curves of $E$. coli by either thermal effect, or solar water disinfection with no dependence of temperature, and the combined effect [8]. Thermal inactivation was modeled with a first order kinetics equation using a kinetic thermal constant as a function of temperature mediated Mancini equation:

$N(t)=N_{0} \cdot e^{-k_{T} \cdot t} \quad k_{T}=\theta^{(T-\alpha)}$

where $N(t)$ and $N_{0}$ are the instantaneous and initial bacterial population respectively, $k_{T}$ is the thermal constant, $t$ is the time, $T$ is the temperature and $\theta$ and $\alpha$ are Mancini fit parameters. Optical inactivation, with no dependence of temperature, was modeled assuming 
two groups of bacterial population, light resistant and light sensitive bacteria:

$N(t)=N_{s} \cdot e^{-k_{s} \cdot t}+N_{R} \cdot e^{-k_{R} \cdot t}$

where $N_{S}$ and $N_{R}$ are the initial light sensitive and light resistant bacterial population respectively and $k_{S}$ and $k_{R}$ are the decay constants for light sensitive and resistant population. The combined effect between radiation and temperature was initially modeled as the additive of the single effects:

$N(t)=N_{s} \cdot e^{-\left(k_{s}+k_{T}\right) \cdot t}+N_{R} \cdot e^{-\left(k_{R}+k_{T}\right) \cdot t}$

However, it was observed that this model underestimated the measured inactivation, demonstrating a relationship between optical and thermal inactivation mechanisms is more than additive but synergistic. To model the synergistic relationship the authors used a 'synergy term', $S$ that takes values larger than 1 when synergy occurs:

$N(t)=N_{S} \cdot e^{-S \cdot\left(k_{S}+k_{T}\right) \cdot t}+N_{R} \cdot e^{-S \cdot\left(k_{R}+k_{T}\right) \cdot t}$

Literature accounts for very little research on modeling solar water disinfection from the microbiological and solar radiation point of view, including the complex intracellular reactions and mechanisms that lead to bacterial inactivation under solar UV radiation. Our previous work proposed a mechanistic model based on the formation of ROS due to UV irradiation and the photoinactivation of CAT and SOD also under the action of solar UV photons. The model successfully reproduced the results at different UV irradiance values $\left(25,30,40 \mathrm{~W} \mathrm{~m}^{-2}\right)$ and at different initial concentrations of E. coli $\left(10^{3}, 10^{4}, 10^{5}, 10^{6} \mathrm{CFU} \mathrm{mL}^{-1}\right)$ [4]. Nevertheless, the mentioned work was developed without taking into consideration the thermal effect since those experiments were performed at temperatures below $30^{\circ} \mathrm{C}$. As mild-heat effect is an important enhancement of the SODIS process, water temperature should be considered as a key factor and included in the model.

The main objective of the present work is to develop a mechanistic model of SODIS including the effect of temperature and to demonstrate that only the synergistic effect between solar UV and mild-heat may explain the results found at different irradiance and water temperature values explored experimentally. Therefore, the present model takes into account the intracellular processes that lead to bacterial inactivation as a result of solar exposure considering water temperature in two manners, i) at individual level, i.e. considering the mere effect of temperature over microorganisms (in dark); and ii) temperature combined with radiation, including the synergistic effect between solar UV and temperature into the photo-induced reactions that occur during solar water disinfection. The new model proposed was demonstrated to describe the time-profile of $E$. coli concentration in clear water at different temperatures in the range from 10 to $55^{\circ} \mathrm{C}$ and under different irradiances ( 30 to $50 \mathrm{~W} \mathrm{~m}^{-2} \mathrm{UV}$ ), thus proving the need of a synergistic component between UV radiation and temperature to successfully reproduce SODIS experimental results.

\section{Materials and methods}

\subsection{E. coli strains, enumeration and quantification}

E. coli strain K12 was obtained from the Spanish Culture Collection (CECT 4624) and used for experiments in distilled water spiked with seeded bacteria. Fresh liquid cultures were prepared in Luria-Bertani nutrient medium (LB Broth, Panreac) and incubated at $37{ }^{\circ} \mathrm{C}$ with rotary shaking for $20 \mathrm{~h}$. The bacterial stationary phase concentration was $10^{9} \mathrm{CFU} \mathrm{\textrm {mL } ^ { - 1 }}$. Bacterial suspensions were harvested by centrifugation at $900 \mathrm{~g}$ for $10 \mathrm{~min}$. Bacterial pellet was re-suspended in phosphate-buffered saline (PBS) solution and diluted to different initial concentration depending on the experiment done. The samples taken during the experiments were enumerated using the standard plate counting method using Luria Bertani agar. Serial 10-fold dilutions in PBS were performed and then three $20 \mu \mathrm{L}$ drops of each dilution were placed in the Petri dish reaching a detection limit of $17 \mathrm{CFU} \mathrm{mL} \mathrm{m}^{-1}$. Colonies were counted after incubation for $24 \mathrm{~h}$ at $37^{\circ} \mathrm{C}$.

\subsection{Thermal inactivation experiments}

The effect of several temperatures from 10 to $55^{\circ} \mathrm{C}$, commonly reached during SODIS process [9], in the dark over the E. coli viability was evaluated in autoclaved distilled water with sodium chloride $(0.9 \% \mathrm{w} / \mathrm{v})$ at different initial bacterial concentrations $\left(10^{3}\right.$ and $\left.10^{6} \mathrm{CFU} \mathrm{mL}^{-1}\right)$. Experiments were performed at different temperatures, $10,20,30,35,37,40,42,45,50$ and $55^{\circ} \mathrm{C}$ using 3 replicates of $2 \mathrm{~mL}$ sterile containers with the bacterial suspension and exposed to each temperature in a cool-hotter dry bath incubator (UniEquip $\mathrm{GmbH}$ ) to maintain temperature constant during the experiment. The temperature values of the experiments were selected depending on the changes in the bacteria viability, being E. coli more sensitive to temperature changes in the range between $35^{\circ} \mathrm{C}$ to $45^{\circ} \mathrm{C}$. Samples were taken at regular times during $5 \mathrm{~h}$ to enumerate the cultivable bacterial cells by the method described above. Results of triplicated experiments were averaged and statistically analyzed; the mean value is shown in the graphs with error bars as the corresponding standard deviation.

\subsection{Solar disinfection experiments}

All experiments were conducted under controlled conditions of solar UV irradiance and water temperature. For this purpose, a solar simulator (Atlas Suntest XLS+, USA) equipped with a xenon lamp and a combination of filters to simulate the solar global radiation outdoors spectrum was used to warrantee constant UV irradiance values along the solar disinfection experiments $(30 \mathrm{~min})$ for each irradiance value selected. UV irradiance was monitored using a UV Solar Light (USA) detector. Water temperature was maintained constant using a thermostat recirculation bath (FrigitermTFT-10, Selecta) into which the solar reactor (explained below) was placed. Temperature was constantly monitored during the $30 \mathrm{~min}$ of solar exposure by a temperature probe. Experiments were performed in an open stirred vessel of $19 \mathrm{~cm}$ diameter, total volume of $700 \mathrm{~mL}$ that was completely illuminated. The water matrix selected for this work was distilled water with sodium chloride $(0.9 \% \mathrm{w} / \mathrm{v})$ to avoid osmotic pressure over bacteria, and the initial concentration of bacteria was $10^{6} \mathrm{CFU} \mathrm{mL}^{-1}$. Experiments were performed three times for each condition, showing high reproducibility (95\% confidence level). The replicates average and error bars calculated as standard deviation are shown in the graphs (Figs. 2, 3, 4). Several solar water disinfection experiments series were done with $\mathrm{E}$. coli at $10^{6} \mathrm{CFU} \mathrm{\textrm {mL } ^ { - 1 }}$ under simulated sunlight. In order to study the effect of irradiance, temperature was maintained constant at $30^{\circ} \mathrm{C}$ and different UV irradiances were tested, 30,40 and $50 \mathrm{~W} \mathrm{~m}^{-2}$. To evaluate the influence of temperature in the solar disinfection, a series of experiments were performed at $30 \mathrm{~W} \mathrm{~m}^{-2}$ of $\mathrm{UV}$, that is the averaged irradiance in a typical sunny day, at differences temperatures, 30,40 and $50{ }^{\circ} \mathrm{C}$. Additionally, other experiments were done at $30 \mathrm{~W} \mathrm{~m}^{-2}$ of solar UV and variable temperature $\left(30-50{ }^{\circ} \mathrm{C}\right)$, varying as a similar rate than it changes during a SODIS experiment under natural solar radiation.

\subsection{Model regression}

Mathematical expressions of the model are coupled system of equations that was solved using the Dormand-Prince method that 
is a Runge-Kutta method for fourth and fifth order solution. The regression of the model was solved using MATLAB ${ }^{\circledR}$ software by the interior-point algorithm. The initial values of the parameters were searched by a Monte Carlo approach. The regression was run minimizing the normalized root mean squared logarithmic error (NRMSLE) of the viable bacteria concentration obtained experimentally and by the model.

\section{Results and discussion: Modelling}

\subsection{Model of dark thermal effect on the E. coli survival}

The effect of temperature in E. coli viability was experimentally evaluated in the range of $10-55^{\circ} \mathrm{C}$. Fig. 1 shows the experimental results of the concentration of cultivable $E$. coli exposed to different

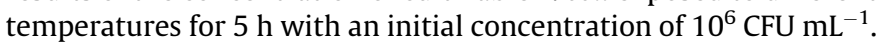
Other values, 10,20 and $30^{\circ} \mathrm{C}$ were also evaluated and no bacterial inactivation was observed (data of 10 and $20^{\circ} \mathrm{C}$ experiments are not shown). At temperature values higher than $30^{\circ} \mathrm{C}$ (from 37 to $55^{\circ} \mathrm{C}$ ) the viability of the bacterial cells was negatively affected so that the higher temperature the lower viability was observed. Similar inactivation profiles were obtained for $10^{3} \mathrm{CFU} \mathrm{mL}^{-1}$ as initial concentration (data not shown). These results are to be expected, in concordance with other results reported in literature [8]. The objective of these experiments was to obtain experimental data for the mathematical 'thermal dark model' fit. This model represents the $E$. coli inactivation due to the mere thermal effect.

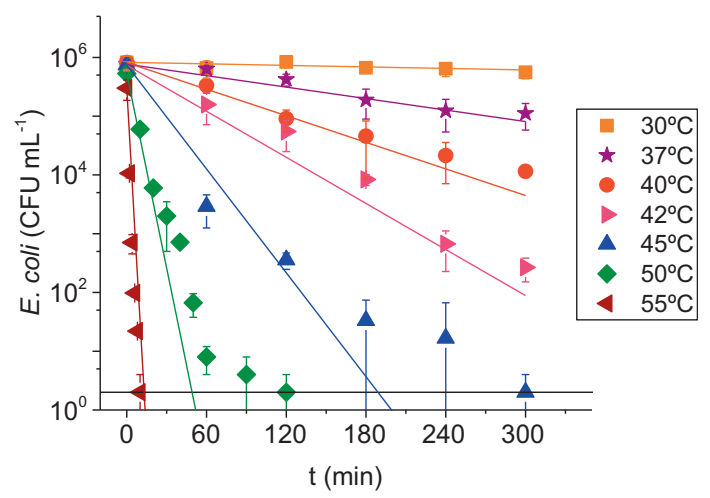

Fig. 1. E. coli thermal inactivation against time (in dark). Experimental results (dots) and log-linear regressions (lines).

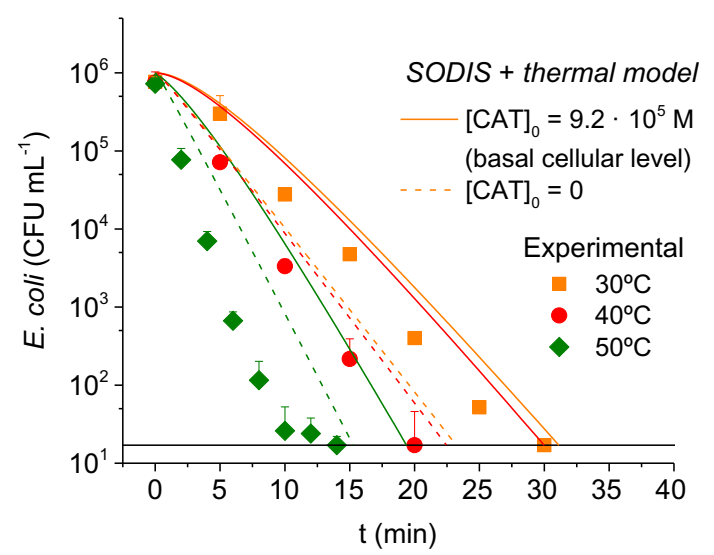

Fig. 2. E. coli inactivation in clear water exposed to simulated sunlight $\left(30 \mathrm{~W} \mathrm{~m}^{-2}\right.$ of UV) at 30,40 and $50^{\circ} \mathrm{C}$. Experimental results (dots) and simulation of SODIS + thermal model (lines), with basal levels of catalase (solid lines) and with no catalase (dashed lines).

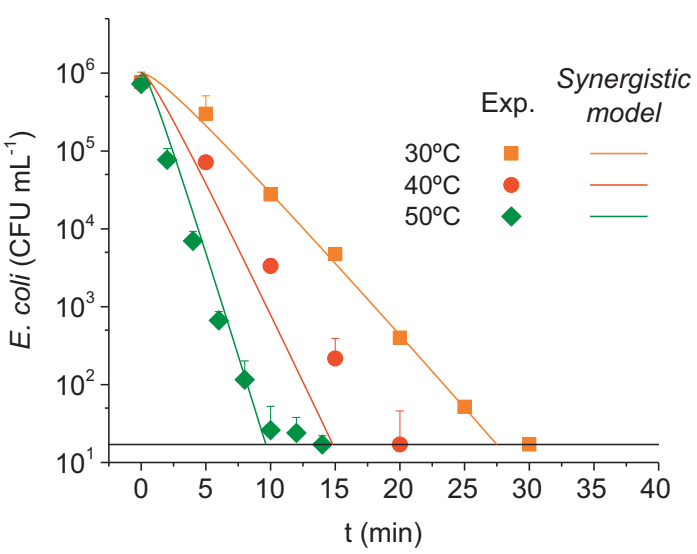

Fig. 3. E. coli inactivation in clear water exposed to simulated sunlight $\left(30 \mathrm{~W} \mathrm{~m}^{-2}\right.$ of UV) at 30,40 and $50^{\circ} \mathrm{C}$. Experimental results (dots) and simulation of synergistic SODIS-thermal model (lines).

The first signal of heat stress is the unfolded outer membrane protein (OMP) in the periplasmatic space, precursor of the activation of the transcription factor $\sigma^{\mathrm{E}}$ (encoded by $r p o E$ ) to start the transcription of the genes required for responding against the heat stress signal. Another signal is the unfolded cytoplasmic proteins
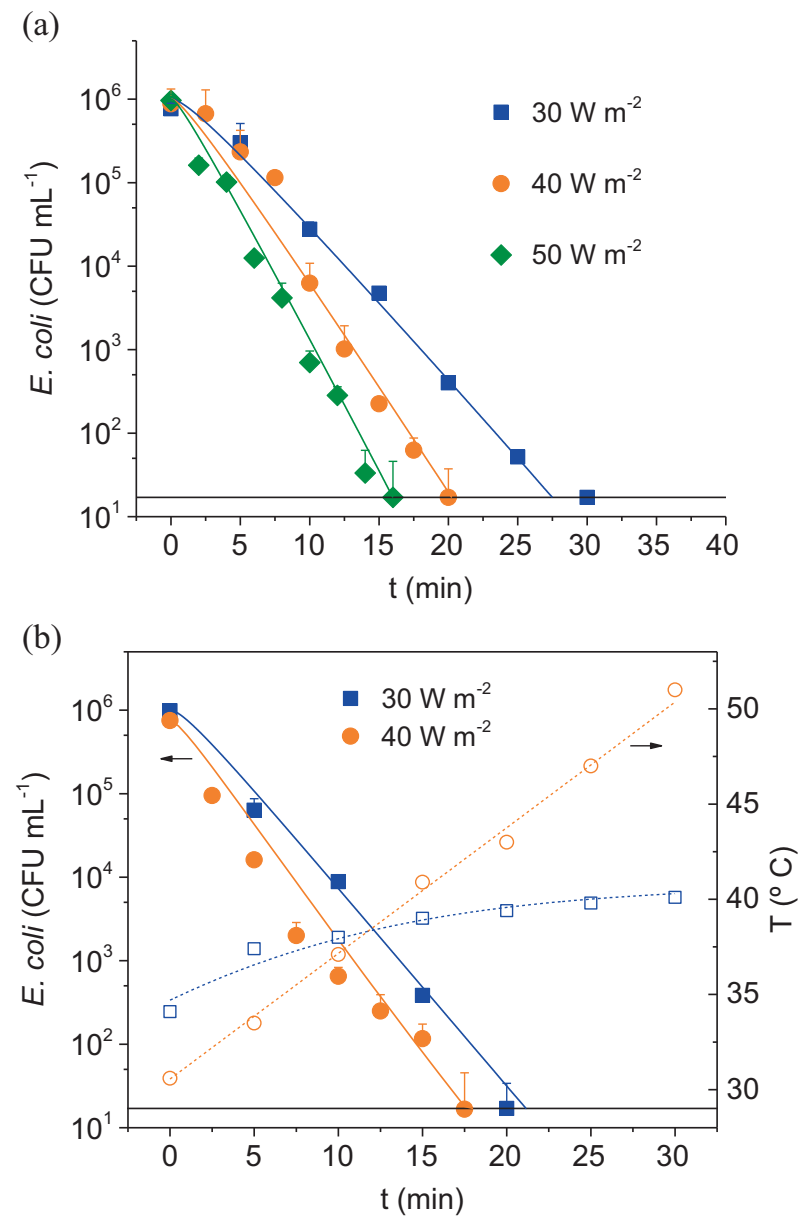

Fig. 4. E. coli inactivation in clear water exposed to simulated sunlight at constant irradiance values of 30,40 and $50 \mathrm{~W} \mathrm{~m}^{-2}$ of UV. Experimental E. coli inactivation results (closed dots), measured temperature (open dots), simulation of synergistic SODIS-thermal model (solid lines) and regression of temperature (dashed lines). (a) at constant temperature equal to $30^{\circ} \mathrm{C}$ and (b) variable temperature $\left(30-50{ }^{\circ} \mathrm{C}\right)$. 
that activate the main heat shock sigma factor $\sigma^{\mathrm{H}}[14]$. The bacterial damages resulted from the heat stress were previously studied. The permeability and the potential of the membrane, esterase activity, intracellular $\mathrm{pH}$ and production of ROS increase due to heat stress were observed [15]. All these injuries lead eventually to a reduction of the bacterial population in water due to the thermal effect.

The mere effect of the temperature on the bacteria viability is represented by a simplified reaction that includes all the mentioned intracellular damages resulting into the transformation of viable bacteria $\left(B_{v}\right)$ to inactive bacteria $\left(B_{i}\right)$ :

$\mathrm{B}_{\mathrm{v}} \stackrel{\mathrm{T}}{\longrightarrow} \mathrm{B}_{\mathrm{i}}$

This model represented by Eq. (5) is called from now on as thermal model. Considering a first order kinetic for the above reaction with a kinetic constant $k_{\mathrm{T}}$, the reaction rate is defined by the following equation:

$r_{\mathrm{B}_{\mathrm{v}}}=\frac{\mathrm{d}\left[\mathrm{B}_{\mathrm{v}}\right]}{\mathrm{dt}}=-k_{\mathrm{T}} \cdot\left[\mathrm{B}_{\mathrm{v}}\right]$

Integrating the above equation, the following expression is obtained:

$\ln \left(\frac{\left[\mathrm{B}_{\mathrm{v}}\right]}{\left[\mathrm{B}_{\mathrm{v}}\right]_{0}}\right)=-k_{\mathrm{T}} \cdot t$

Thus, the kinetic constant $k_{\mathrm{T}}$ for each temperature could be calculated by linear regression as the slope of the line where $t$ is the independent variable and $\ln \left(\left[\mathrm{B}_{\mathrm{v}}\right] /\left[\mathrm{B}_{\mathrm{v}}\right]_{0}\right)$ is the dependent variable. Using the experimental data shown in Fig. $1, k_{\mathrm{T}}$ values for each temperature and for both experimental conditions, i.e. $10^{3}$ and $10^{6} \mathrm{CFU} \mathrm{mL}^{-1}$ as initial bacterial concentration, were fitted. $k_{\mathrm{T}}$ values are shown in Table 1 , showing that kinetic constant $k_{\mathrm{T}}$ is temperature dependant. The correlation between $k_{\mathrm{T}}$ and $\mathrm{T}$ is defined by Arrhenius law:

$\ln k_{\mathrm{T}}=\ln A-\frac{E a}{R \cdot \mathrm{T}}$

where $A$ is the pre-exponential factor, Ea the activation energy and $R$ the ideal gas constant. For the determination of the Arrhenius parameters, a linear regression was done showing, $\ln A=79 \pm 3$ $\left(A, \mathrm{~s}^{-1}\right)$, and $E a=(23 \pm 1) \cdot 10^{4} \mathrm{~J} \mathrm{~mol}^{-1}$.

\subsection{Model of solar disinfection without considering temperature}

Firstly, the solar disinfection model with no dependence on temperature used in this work has been previously developed and reported [4]. Briefly, it is based on the photo-induced overgeneration of ROS and the photo-inactivation of the protective enzymes inside bacterial cells when exposed to prolonged

Table 1

Kinetic thermal constant values for dark thermal inactivation of E. coli at different temperatures and initial bacterial concentration.

\begin{tabular}{lll}
\hline Temperature & $\begin{array}{l}k_{\mathrm{T}}\left(\mathrm{min}^{-1}\right) \text { Experiments } \\
\text { with }\left[\mathrm{B}_{\mathrm{v}}\right]_{0}=10^{6} \mathrm{CFU} \mathrm{mL}^{-1}\end{array}$ & $\begin{array}{l}k_{\mathrm{T}}\left(\mathrm{min}^{-1}\right) \text { Experiments } \\
\text { with }\left[\mathrm{B}_{\mathrm{v}}\right]_{0}=10^{3} \mathrm{CFU} \mathrm{mL} \mathrm{m}^{-1}\end{array}$ \\
\hline $10^{\circ} \mathrm{C}$ & $0.0008 \pm 0.0002$ & $0.0003 \pm 0.0003$ \\
$20^{\circ} \mathrm{C}$ & $0.0011 \pm 0.0001$ & $0.0007 \pm 0.0004$ \\
$30^{\circ} \mathrm{C}$ & $0.0012 \pm 0.0002$ & $0.0014 \pm 0.0004$ \\
$35^{\circ} \mathrm{C}$ & $0.0030 \pm 0.0002$ & $0.0030 \pm 0.0005$ \\
$37^{\circ} \mathrm{C}$ & $0.0068 \pm 0.0004$ & $0.0074 \pm 0.0002$ \\
$40^{\circ} \mathrm{C}$ & $0.0151 \pm 0.0005$ & $0.019 \pm 0.002$ \\
$42^{\circ} \mathrm{C}$ & $0.0266 \pm 0.0009$ & $0.035 \pm 0.005$ \\
$45{ }^{\circ} \mathrm{C}$ & $0.048 \pm 0.004$ & $0.080 \pm 0.004$ \\
$50{ }^{\circ} \mathrm{C}$ & $0.182 \pm 0.005$ & $0.29 \pm 0.01$ \\
$55^{\circ} \mathrm{C}$ & $1.25 \pm 0.05$ & - \\
\hline
\end{tabular}

sunlight. This model will be so-called from now on SODIS model. The reactions that represent this complex mechanistic process are summarized in Table 2.

The main intracellular species involved in photo-inactivation of bacteria in water by solar radiation are: (i) ROS as superoxide radical $\left(\mathrm{O}_{2}^{-}\right)$, hydrogen peroxide $\left(\mathrm{H}_{2} \mathrm{O}_{2}\right)$, hydroxyl radical (HO-) and hydroperoxyl radical $\left(\mathrm{HO}_{2}\right)$; (ii) free iron species in the form of ferrous $\left(\mathrm{Fe}^{2+}\right)$ and ferric ions $\left(\mathrm{Fe}^{3+}\right)$; (iii) enzymes as catalase (CAT) and superoxide dismutase (SOD) and (iv) the susceptible targets to be oxidized by ROS that are enclosed in a unique group called $\mathrm{OM}$, acronym of organic matter, which is presented in two states, reduced (red) and oxidized (ox). Sunlight takes part in four reactions: (i) in the formation of $\mathrm{O}_{2}^{-}$from oxygen and free electrons proceeding from the electron transport chain, (ii) intracellular photo-Fenton reactions in which labile free iron is involved and (iii) the photo-inactivation of the enzymes (CAT and SOD). The reaction Eq. (T2.13) represents the bacterial inactivation as the transformation of viable bacteria $\left(B_{v}\right)$ to inactive bacteria $\left(B_{i}\right)$ mediated by $\mathrm{HO}^{\cdot}$ and $\mathrm{O}_{2}^{-}$.

Light intensity is introduced in the kinetic rate expressions by the local volumetric rate of photon absorption (LVRPA, $e^{\mathrm{a}}$ ) that could be calculated by the following equation:

$e_{i}^{a}=\int_{\lambda_{1}}^{\lambda_{2}} \kappa_{\lambda, i} \cdot G_{\lambda} \mathrm{d} \lambda$

where $\kappa_{\lambda, i}$ is the absorption coefficient of the compound $i$ at $\lambda$ wavelength in terms of $\mathrm{cm}^{-1}$, and $\mathrm{G}_{\lambda}$ is the incident radiation at $\lambda$ wavelength in terms of Einstein $\mathrm{cm}^{-2} \mathrm{~s}^{-1}$. The estimation of the LVRPA for each absorbent component in the reactor (CAT, SOD and the photosensitizier NADH) is explained elsewhere [4]. In this work, the assumptions and simplifications applied are explained in detail. Briefly these are (i) one-dimensional light transport, (ii) LVRPA is constant in the entire photo-reactor volume, (iii) LVRPA is constant over time, and (iv) light parameters are averaged in the solar UV range (300-400 $\mathrm{nm})$.

\subsection{Model of the combined effect of UV and mild-heat action}

\subsubsection{SODIS + thermal model}

The two models explained above were combined by the simple addition of Eq. (5) (thermal model) to the equations of Table 2 (SODIS model). The two models individually give account for cells inactivation due to the mere action of temperature (in the dark) and due to the action of only solar radiation (with no dependence on temperature), respectively. This model is the simplest strategy to explain the solar water disinfection at mild-heat temperatures reached during SODIS, rising from 25 to $55^{\circ} \mathrm{C}$, since it is the addition of the two single effects with no consideration of any extra beneficial action of temperature over SODIS [8].

It is necessary to notice that the mass balance of viable bacteria has to be proposed for the entire reactor using the thermal model, Eq. (5) and the reaction Eq. (T2.13) of the SODIS model. On the contrary, the rest of the reactions of the SODIS model are intracellular reactions and have to be used for solving the mass balance at intracellular level, for internal species in a single cell. According to the isotropic hypothesis, the same internal reactions will occur in all cells without population, time or space preferences. Consequently, the changes over time on the concentration of the intracellular species involved in the process could be considered the same in all cells. The two following assumptions have been made to solve the mass balances: (i) kinetic micro steady-state approximation for concentration of iron $\left(\mathrm{Fe}^{2+}\right.$ and $\left.\mathrm{Fe}^{3+}\right)$ and radicals $\left(\mathrm{O}_{2}^{-}, \mathrm{HO}\right.$. and $\mathrm{HO}_{2}$ ) inside a bacterial cell, and (ii) iron released from cluster due to oxidative stress is neglected. The mass balance of the viable bacteria is given by the following equation: 
Table 2

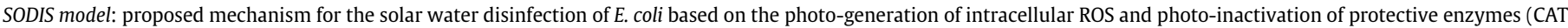
and SOD), adapted from [4].

\begin{tabular}{|c|c|c|}
\hline & Reaction & Kinetic constant value \\
\hline Eq. (T2.1) & $\mathrm{O}_{2}+\mathrm{e}^{-} \rightarrow \mathrm{O}_{2}^{--}$ & $k_{1}=2 \cdot 10^{10} \mathrm{M}^{-1} \mathrm{~s}^{-1}$ \\
\hline Eq. (T2.2) & $\mathrm{O}_{2}+\mathrm{e}^{-} \stackrel{\mathrm{h} v, \mathrm{NADH}}{\longrightarrow} \mathrm{O}_{2}^{-}$ & $k_{2}=4.22 \cdot 10^{20} \mathrm{~cm}^{3}$ Einstein ${ }^{-1} \mathrm{M}^{-1}$ \\
\hline Eq. (T2.3) & $\mathrm{O}_{2}^{-}+\mathrm{H}^{+} \stackrel{\mathrm{SOD}}{\longrightarrow} \frac{1}{2} \mathrm{H}_{2} \mathrm{O}_{2}+\frac{1}{2} \mathrm{O}_{2}$ & $k_{3}=10^{9} \mathrm{M}^{-1} \mathrm{~s}^{-1}$ \\
\hline Eq. (T2.4) & $\mathrm{Fe}^{2+}+\mathrm{H}_{2} \mathrm{O}_{2} \rightarrow \mathrm{Fe}^{3+}+\mathrm{HO}^{-}+\mathrm{HO}^{-}$ & $k_{4}=70 \mathrm{M}^{-1} \mathrm{~s}^{-1}$ \\
\hline Eq. (T2.5) & $\mathrm{Fe}^{3+}+\mathrm{H}_{2} \mathrm{O} \stackrel{\mathrm{h} v}{\longrightarrow} \mathrm{Fe}^{2+}+\mathrm{HO}+\mathrm{H}^{+}$ & \\
\hline Eq. (T2.6) & $\mathrm{H}_{2} \mathrm{O}_{2}+\mathrm{HO} \rightarrow \mathrm{HO}_{2}+\mathrm{H}_{2} \mathrm{O}$ & $k_{6}=2.7 \cdot 10^{7} \mathrm{M}^{-1} \mathrm{~s}^{-1}$ \\
\hline Eq. (T2.7) & $\mathrm{HO}_{2} \rightarrow \frac{1}{2} \mathrm{H}_{2} \mathrm{O}_{2}+\frac{1}{2} \mathrm{O}_{2}$ & $k_{7}=8.3 \cdot 10^{5} \mathrm{M}^{-1} \mathrm{~s}^{-1}$ \\
\hline Eq. (T2.8) & $\mathrm{H}_{2} \mathrm{O}_{2} \stackrel{\text { CAT }}{\longrightarrow} \frac{1}{2} \mathrm{O}_{2}+\mathrm{H}_{2} \mathrm{O}$ & $k_{8}=9 \cdot 10^{5} \mathrm{M}^{-1} \mathrm{~s}^{-1}$ \\
\hline Eq. (T2.9) & $\mathrm{CAT} \stackrel{\mathrm{h} v}{\longrightarrow} \mathrm{CAT}_{\mathrm{i}}$ & $k_{9}=1.5 \cdot 10^{7} \mathrm{~cm}^{3}$ Einstein $^{-1}$ \\
\hline Eq. (T2.10) & $\mathrm{SOD} \stackrel{\mathrm{h} v}{\longrightarrow}$ SOD $_{\mathrm{i}}$ & $k_{10}=1.56 \cdot 10^{6} \mathrm{~cm}^{3}$ Einstein $^{-1}$ \\
\hline Eq. (T2.11) & $\mathrm{OM}_{\mathrm{red}}+\mathrm{HO}^{1} \rightarrow \mathrm{OM}_{\mathrm{ox}}$ & $k_{11}=2.04 \cdot 10^{4} \mathrm{~s}^{-1}$ \\
\hline Eq. (T2.12) & $\mathrm{OM}_{\mathrm{red}}+\mathrm{O}_{2}^{--} \rightarrow \mathrm{OM}_{\mathrm{ox}}$ & $k_{12}=1.36 \cdot 10^{5} \mathrm{~s}^{-1}$ \\
\hline Eq. (T2.13) & $\mathrm{B}_{\mathrm{V}} \stackrel{\mathrm{HO}, \mathrm{O}_{2}^{-}}{\longrightarrow} \mathrm{B}_{\mathrm{i}}$ & $k_{13}=8.03 \cdot 10^{15} \mathrm{M}^{-2} \mathrm{~s}^{-1}$ \\
\hline
\end{tabular}

$\frac{\mathrm{d}\left[\mathrm{B}_{\mathrm{v}}\right]}{\mathrm{dt}}=-k_{13}[\mathrm{HO}]\left[\mathrm{O}_{2}^{-}\right]\left[\mathrm{B}_{\mathrm{v}}\right]-k_{\mathrm{T}}\left[\mathrm{B}_{\mathrm{v}}\right]$

Eq. (10) was solved simultaneously with the mass balances of the rest of the intracellular species involved in the model, SOD, CAT, $\mathrm{H}_{2} \mathrm{O}_{2}$, $\mathrm{HO}$ and $\mathrm{O}_{2}^{--}$(not shown).

Fig. 2 shows the $E$. coli inactivation by solar water disinfection at different temperatures 30,40 , and $50{ }^{\circ} \mathrm{C}$ under $30 \mathrm{~W} \mathrm{~m}^{-2}$ of UV radiation. The experimental results are represented (dots) together with the predictions given by the SODIS + thermal model (lines). Two types of simulations were run: (1) using the basal levels of all the intracellular species involved in the process (solid lines) and (2) with concentration of CAT equal to zero (dashed lines, explained in next section). The profiles predicted by the model with basal levels of catalase are significantly slower than experimental data, underestimating the bacterial inactivation efficiency that was really observed in the SODIS experiments at the three selected temperatures. This result clearly suggests that the relationship between temperature and solar radiation mechanisms is much more than the mere addition of the two single effects. This is clear experimental evidence about the synergistic effect between temperature and sunlight occurring during solar water disinfection process. This result is in concordance with the reported by McGuigan et al. [8] that reached the same conclusion with empirical regressions.

\subsubsection{Is thermal inactivation of catalase a key point?}

Catalase is an intracellular enzyme that plays a very important role in the defensive action against cellular oxidative stress. Due to the biological nature of this protein, it is one of the main targets that are susceptible to be affected by temperature and solar radiation. In fact, in SODIS model, the photo-inactivation of CAT is estimated to be significantly fast. Photo-inactivation kinetic constant of catalase is 10 times higher than SOD [4]. The kinetics of catalase inactivation within the temperature range of $30-60{ }^{\circ} \mathrm{C}$ was previously investigated [16]. Catalase thermo-inactivation was characterized by relative initial rates, which increased with incubation time and temperature increase.

According to this, catalase is also expected to have a key role in the $E$. coli inactivation by the synergistic effect of solar radiation and thermal increase. With the aim of analyzing the importance of catalase activity in the defense mechanisms of bacteria against the oxidative stress, simulation of the SODIS + thermal model was run in the absence of any catalase, i.e. $[\mathrm{CAT}]_{0}=0$. Fig. 2 shows the predicted values for bacteria inactivation using the model
SODIS + thermal model with $[\text { CAT }]_{0}=0$ (dashed lines). As expected, since catalase is a bacterial defensive enzyme, simulations without catalase result in a faster bacterial inactivation than with catalase (solid lines, Fig. 2). It is also observed at $30^{\circ} \mathrm{C}$ that the inactivation profile simulated is faster than experimental E. coli behavior. This fact indicates that catalase is still effective at $30^{\circ} \mathrm{C}$, which gets to reduce the bacterial inactivation rate as shown in the experimental results at $30^{\circ} \mathrm{C}$. However, at 40 and $50{ }^{\circ} \mathrm{C}$, the simulation results without catalase are closer to the experimental results, but they still underestimated the bacterial inactivation experimentally measured. Thus, although catalase is a susceptible radiation target, when cells are exposed to oxidative stress, there must be other intracellular targets participating in the process accounting for an accelerated bacterial inactivation.

\subsubsection{Synergistic SODIS-thermal model}

According to previous results, we may conclude that mild-heat improves solar disinfection efficiency and this factor must be considered as part of the solar process, i.e. taking part of some intracellular reactions promoted by solar exposure as a synergistic factor. Although catalase is a very important species in this process, it was proven that is not the only compound affected by this effect. Thus, the SODIS + thermal model was modified including this synergistic effect, leading to a new proposed model that predicts the behavior of the intracellular species and the concentration of viable bacteria when they are exposed to solar UV radiation and taking into account the thermal factor for mild temperature values (30 to 55 ${ }^{\circ} \mathrm{C}$ ). The enhanced model is called from now on 'synergistic SODIS-thermal model', that is summarized in Table 3. Each step of the model is explained in detail below.

3.3.3.1. Intracellular ROS formation. Several ROS are formed in the interior of the cells due to the sunlight and temperature actions:

I. Superoxide radicals: The intracellular molecular oxygen is reduced to $\mathrm{O}_{2}^{--}$by electrons that come from the electron transport chain process. This reduction occurs by natural ways in the inner cells by Eq. (T3.1). The thermal effect was included in the model using the Arrhenius parameters reported elsewhere [17]. $\mathrm{O}_{2}^{-}$is also formed by photoinducted reduction of oxygen in presence of some photosensitizers as NADH [4]. This reaction is represented by Eq. (T3.2). Temperature was also considered in this reaction through Arrhenius parameters that are unknown, so they were taken as model's parameters $\left(k_{2}\right.$ and $\left.E a_{2}\right)$. 
Table 3

Synergistic SODIS-thermal model: proposed mechanism for the synergistic effect between mild-heat and solar water disinfection of $E$. coli

\begin{tabular}{|c|c|c|c|c|}
\hline & Reaction & Rate & Kinetic constant & Arrhenius parameters \\
\hline Eq. (T3.1) & $\mathrm{O}_{2}+\mathrm{e}^{-} \stackrel{T}{\longrightarrow} \mathrm{O}_{2}^{--}$ & $k_{1}\left[\mathrm{O}_{2}\right]\left[\mathrm{e}^{-}\right]$ & $k_{1}(\mathrm{~T})=A_{1} \cdot \exp \left(\frac{-E a_{1}}{R \cdot \mathrm{T}}\right)$ & $A_{1}=3.16 \cdot 10^{12} \mathrm{M}^{-1} \mathrm{~s}^{-1} \mathrm{Ea}_{1}=1.3 \cdot 10^{4} \mathrm{~J} \mathrm{~mol}^{-1}[17]$ \\
\hline Eq. (T3.2) & $\mathrm{O}_{2}+\mathrm{e}^{-} \stackrel{\mathrm{h} v, N A D H, T}{\longrightarrow} \mathrm{O}_{2}^{--}$ & $k_{2}\left[\mathrm{O}_{2}\right]\left[\mathrm{e}^{-}\right] \mathrm{e}_{\mathrm{NADH}}^{\mathrm{a}}$ & $k_{2}(\mathrm{~T})=A_{2} \cdot \exp \left(\frac{-E a_{2}}{R \cdot \mathrm{T}}\right)$ & \\
\hline Eq. (T3.3) & $\mathrm{O}_{2}^{--}+\mathrm{H}^{+} \stackrel{\mathrm{SOD}}{\longrightarrow} \frac{1}{2} \mathrm{H}_{2} \mathrm{O}_{2}+\frac{1}{2} \mathrm{O}_{2}$ & $k_{3}\left[O_{2}^{-}\right][\mathrm{SOD}]$ & $k_{3}=10^{9} \mathrm{M}^{-1} \mathrm{~s}^{-1}[6]$ & \\
\hline Eq. (T3.4) & $\mathrm{Fe}^{2+}+\mathrm{H}_{2} \mathrm{O}_{2} \stackrel{\mathrm{T}}{\longrightarrow} \mathrm{Fe}^{3+}+\mathrm{HO}^{-}+\mathrm{HO}$ & $k_{4}\left[\mathrm{Fe}^{2+}\right]\left[\mathrm{H}_{2} \mathrm{O}_{2}\right]$ & $k_{4}(\mathrm{~T})=A_{4} \cdot \exp \left(\frac{-E a_{4}}{R \cdot \mathrm{T}}\right)$ & $A_{4}=1.92 \cdot 10^{9} \mathrm{M}^{-1} \mathrm{~s}^{-1} \mathrm{Ea}_{4}=4.68 \cdot 10^{4} \mathrm{~J} \mathrm{~mol}^{-1}[18]$ \\
\hline Eq. (T3.5) & $\mathrm{Fe}^{3+}+\mathrm{H}_{2} \mathrm{O} \stackrel{\mathrm{h} v, \mathrm{~T}}{\longrightarrow} \mathrm{Fe}^{2+}+\mathrm{HO}+\mathrm{H}^{+}$ & $k_{5}\left[\mathrm{Fe}^{3+}\right]\left[\mathrm{H}_{2} \mathrm{O}\right] \mathrm{e}_{\mathrm{Fe}^{3+}}^{\mathrm{a}}$ & $k_{5}(\mathrm{~T})=A_{5} \cdot \exp \left(\frac{-E a_{5}}{R \cdot \mathrm{T}}\right)$ & \\
\hline Eq. (T3.6) & $\mathrm{H}_{2} \mathrm{O}_{2}+\mathrm{HO} \rightarrow \mathrm{HO}_{2}+\mathrm{H}_{2} \mathrm{O}$ & $k_{6}\left[\mathrm{H}_{2} \mathrm{O}_{2}\right]\left[\mathrm{HO}^{\circ}\right]$ & $k_{6}=2.7 \cdot 10^{7} \mathrm{M}^{-1} \mathrm{~s}^{-1}[17]$ & \\
\hline Eq. (T3.7) & $\mathrm{HO}_{2} \rightarrow \frac{1}{2} \mathrm{H}_{2} \mathrm{O}_{2}+\frac{1}{2} \mathrm{O}_{2}$ & $k_{7}\left[\mathrm{HO}_{2}\right]^{2}$ & $k_{7}=8.3 \cdot 10^{5} \mathrm{M}^{-1} \mathrm{~s}^{-1}[19]$ & \\
\hline Eq. (T3.8) & $\mathrm{H}_{2} \mathrm{O}_{2} \stackrel{\text { CAT }}{\longrightarrow} \frac{1}{2} \mathrm{O}_{2}+\mathrm{H}_{2} \mathrm{O}$ & $k_{8}\left[\mathrm{H}_{2} \mathrm{O}_{2}\right][\mathrm{CAT}]$ & $k_{8}=9 \cdot 10^{5} \mathrm{M}^{-1} \mathrm{~s}^{-1}[20]$ & \\
\hline Eq. (T3.9) & $\mathrm{CAT} \rightarrow \mathrm{CAT}_{\mathrm{i}}$ & $k_{9}[\mathrm{CAT}] \mathrm{e}_{\mathrm{CAT}}^{\mathrm{a}}$ & $k_{9}(\mathrm{~T})=A_{9} \cdot \exp \left(\frac{-E a_{9}}{R \cdot T}\right)$ & \\
\hline Eq. (T3.10) & $\mathrm{SOD} \stackrel{\mathrm{h} v}{\longrightarrow} \mathrm{SOD}_{i}$ & $k_{10}[\mathrm{SOD}] \mathrm{e}_{\mathrm{SOD}}^{\mathrm{a}}$ & $k_{10}=1.56 \cdot 10^{6} \mathrm{~cm}^{-3}$ Einstein $^{-1}[4]$ & \\
\hline Eq. (T3.11) & $\mathrm{OM}_{\mathrm{red}}+\mathrm{HO} \rightarrow \mathrm{OM}_{\mathrm{ox}}$ & $k_{11}[\mathrm{HO}]$ & $k_{11}=2.04 \cdot 10^{4} \mathrm{~s}^{-1}[4]$ & \\
\hline Eq. (T3.12) & $\mathrm{OM}_{\mathrm{red}}+\mathrm{O}_{2}^{--} \rightarrow \mathrm{OM}_{\mathrm{ox}}$ & $k_{12}\left[\mathrm{O}_{2}^{-}\right]$ & $k_{12}=1.36 \cdot 10^{5} \mathrm{~s}^{-1}[4]$ & \\
\hline Eq. (T3.13) & $\mathrm{B}_{\mathrm{V}} \stackrel{\mathrm{HO}, \mathrm{O}_{2}^{-}}{\longrightarrow} \mathrm{B}_{\mathrm{i}}$ & $k_{13}\left[\mathrm{HO}^{\prime}\right]\left[\mathrm{O}_{2}^{--}\right]\left[\mathrm{B}_{\mathrm{v}}\right]$ & $k_{13}=8.03 \cdot 10^{15} \mathrm{M}^{-2} \mathrm{~s}^{-1}[4]$ & \\
\hline Eq. (T3.14) & $\mathrm{B}_{\mathrm{v}} \stackrel{\mathrm{T}}{\longrightarrow} \mathrm{B}_{\mathrm{i}}$ & $k_{14}\left[\mathrm{~B}_{\mathrm{v}}\right]$ & $k_{14}(\mathrm{~T})=A_{14} \cdot \exp \left(\frac{-E a_{14}}{R \cdot \mathrm{T}}\right)$ & $A_{14}=1.30 \cdot 10^{34} \mathrm{~s}^{-1} E a_{14}=2.26 \cdot 10^{5} \mathrm{~J} \mathrm{~mol}^{-1}$ (this work) \\
\hline
\end{tabular}

The intracellular oxygen concentration is equivalent to extracellular oxygen [21], i.e. the dissolved oxygen in water. This parameter is temperature dependent ranging from 236 to $177 \mu \mathrm{M}$, at 30 to $50{ }^{\circ} \mathrm{C}$, respectively. Nevertheless, the maximum intracellular oxygen concentration permitted for bacteria is $210 \mu \mathrm{M}$, in airsaturated bacterial cells [21]. We have considered in our model the effect of the temperature on dissolved oxygen inside the cell, at the range of temperatures evaluated in this work (data not shown). Nevertheless, the little differences between these values produce negligible differences in the model results, and it was finally assumed the value of $210 \mu \mathrm{M}$ for all the cases studied.

II. Hydrogen peroxide: Superoxide radicals are converted to $\mathrm{H}_{2} \mathrm{O}_{2}$ in a reaction catalyzed by SOD (Eq. (T3.3)). Up to date, this reaction has been widely studied although not thermal dependence has been reported.

III. Hydroxyl radicals: HO are formed by thermal Fenton and photo-Fenton process that is a complex set of reactions with high dependency on $\mathrm{pH}$ and temperature. The main reactions are summarized [18]:

$$
\begin{aligned}
& \mathrm{Fe}^{3+}+\mathrm{H}_{2} \mathrm{O} \stackrel{\mathrm{h} v, \mathrm{~T}}{\longrightarrow} \mathrm{Fe}^{2+}+\mathrm{HO}^{+}+\mathrm{H}^{+} \\
& \mathrm{Fe}^{2+}+\mathrm{H}_{2} \mathrm{O}_{2} \stackrel{\mathrm{T}}{\longrightarrow} \mathrm{Fe}^{3+}+\mathrm{HO}^{-}+\mathrm{HO}^{\circ} \\
& \mathrm{Fe}^{3+}+\mathrm{H}_{2} \mathrm{O}_{2} \stackrel{\mathrm{T}}{\longrightarrow} \mathrm{Fe}^{2+}+\mathrm{H}^{+}+\mathrm{HO}_{2} \\
& \mathrm{Fe}^{3+}+\mathrm{HO}_{2} \rightarrow \mathrm{Fe}^{2+}+\mathrm{H}^{+}+\mathrm{O}_{2} \\
& \mathrm{Fe}^{2+}+\mathrm{HO}_{2}+\mathrm{H}^{+} \rightarrow \mathrm{Fe}^{3+}+\mathrm{H}_{2} \mathrm{O}_{2} \\
& \mathrm{Fe}^{2+}+\mathrm{HO}^{\rightarrow} \mathrm{Fe}^{3+}+\mathrm{HO}^{-}
\end{aligned}
$$

Farias et al. considered that thermal effect on the reactions Eqs. (14) to (16) can be neglected [18]. For modeling purposes, some simplifications were done: (i) reaction of Eq. (13) was neglected because is a very slow reaction $\left(2 \cdot 10^{-3} \mathrm{M}^{-1} \mathrm{~s}^{-1}\right.$ [22]) in comparison with Eq. (12) $\left(70 \mathrm{M}^{-1} \mathrm{~s}^{-1}\right)$, (ii) reactions of Eqs. (14) and (15) were also neglected due to $\mathrm{HO}_{2}$ was not considered in this simplified model, and (iii) from the point of view of HO- reactivity, reaction Eq. (T3.11) $\left(2.04 \cdot 10^{4} \mathrm{~s}^{-1}\right)$ is predominant over reaction Eq. (16) $\left(k_{\text {apparent }}=10^{2} \mathrm{~s}^{-1}[23]\right)$; then reaction Eq. (16) was also neglected. Thus, only reactions Eqs. (11) and (12) were considered in this model (Eq. (T3.4) and Eq. (T3.5)). To include the thermal effect in these reactions, the Arrhenius parameters reported by Farias et al. were used [18].

ROS recombination: due to the high reactivity of ROS, there are some important recombination reactions, also considered in other kinetic models; these are Eq. (T3.6) and Eq. (T3.7) [18,22]. The effect of temperature in these reactions was considered negligible as previously studied by Farias et al. [18].

3.3.3.2. Hydrogen peroxide decomposition. $\mathrm{H}_{2} \mathrm{O}_{2}$ is naturally decomposed to water and oxygen by the catalytic action of CAT inside cells (Eq. (T3.8)). Temperature has not been reported to affect this reaction mediated by CAT.

3.3.3.3. Enzymes photo-inactivation. The activity of the enzymes involved in the processes of ROS decomposition may be affected by thermal and photon action (Eq. (T3.9) and Eq. (T3.10)). Thermal effect was included in the kinetics of CAT photo-inactivation by Arrhenius parameters. For modeling purposes, the following assumption was done: the value of $k_{9}$ obtained for the SODIS model $\left(1.5 \cdot 10^{7} \mathrm{~cm}^{3}\right.$ Einstein $\left.^{-1}\right)$ is valid for $25^{\circ} \mathrm{C}, k_{9,25}{ }^{\circ} \mathrm{C}$. Then, the preexponential factor $A_{9}$ is obtained by the following equation, resulting in only one model parameter, $E a_{9}$ :

$A_{9}=k_{9,25}{ }^{\circ} \mathrm{C} \cdot \exp \left(\frac{E a_{9}}{R \cdot(25+273)}\right)$

The thermal effect was not considered in SOD photoinactivation due to SOD has fair thermal stability with a maximum activity in the range of $37-50^{\circ} \mathrm{C}[24,25]$, being affected only by temperature values higher than $70^{\circ} \mathrm{C}$ [26]. Also, it was previously observed that the role of SOD compared with catalase is nearly negligible during the solar disinfection process [4].

3.3.3.4. Cellular damages and bacteria inactivation. The most reactive ROS are $\mathrm{HO}^{-}$or $\mathrm{O}_{2}^{-}$. They are considered the main responsible for cellular damages by ROS inside cells [27]. ROS's attacks to several intracellular targets were encompassed in the reactions Eq. (T3.11) and Eq. (T3.12) that include the oxidation of the organic matter susceptible to be oxidized $\left(\mathrm{OM}_{\mathrm{red}}\right)$ by $\mathrm{HO}^{\cdot}$ or $\mathrm{O}_{2}^{--}$. In this case we have assumed that temperature has a negligible effect due to the very high reactivity of ROS at this range of temperatures.

Finally, bacteria are considered to be inactivated due to the action of either ROS (Eq. (T3.13)) or temperature (Eq. (T3.14)). Eq. (T3.13) has a very high kinetic constant, and the effect of T $\left[10-55^{\circ} \mathrm{C}\right]$ was considered negligible in relation to Eq. (T3.14). 
The reaction of Eq. (T3.14) represents the cellular inactivation due to all of the direct damages caused by temperature with no effect of light. This reaction corresponds to Eq. (5), with Arrhenius parameters previously determined [4].

Mass balance for each species involved in the process can be solved for a single cell volume while mass balance of viable bacteria has to be solved in the whole reactor volume (details in the appendix). To predict the change over time of the bacterial concentration or the internal species concentrations, it is necessary to solve simultaneously the differential equations that define the concentration of viable bacteria, ROS and enzymes. To do so, the three regression parameters of the model, $A_{2}, E a_{2}$ and $E a_{9}$ are correlated minimizing the NRMSLE with the experimental data. The experimental results used for this were obtained from solar disinfection experiments performed at different temperatures (30, 40 and $50{ }^{\circ} \mathrm{C}$ ) and $30 \mathrm{~W} \mathrm{~m}^{-2}$ of $\mathrm{UV}$. Values obtained for these parameters and the NRMSLE are:

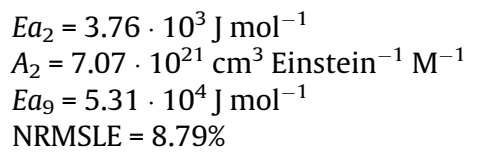

Fig. 3 shows the experimental and model results in the different evaluated conditions. This evidences that the model results using the optimized parameters fit satisfactorily experimental results. Even, the NRMSLE calculated for all the experiments is lower than $10 \%$, which can be considered an excellent regression result [28].

It is important to note that parameters' values obtained in this work are specifically obtained for the operational conditions of the experiments done, i.e. the type of microorganism and its growth phase, the reactor setup that determine the inlet UV or the water matrix that could have scavenger compounds or interfere the UV absorption.

\subsection{Validation of the synergistic SODIS-thermal model}

This mechanistic model was obtained by regression with experimental data of the inactivation of $E$. coli by simulated sunlight at different temperatures and $30 \mathrm{~W} \mathrm{~m}^{-2}$ of UV. The validation of the proposed model was developed under different irradiances and in two different scenarios: (i) keeping the water temperature constant and (ii) increasing the temperature during the solar water disinfection process to simulate the real conditions of the SODIS process. Fig. 4 shows the experimental and the simulated data of E. coli inactivation at different irradiances values. The experiments represented in Fig. 4(a) were performed at a constant temperature of $30^{\circ} \mathrm{C}$ while experiments of Fig. 4(b) were carried out with variable temperature ramped from $30-35^{\circ} \mathrm{C}$ to $40-50{ }^{\circ} \mathrm{C}$. It is observed that model data fit accurately the experimental data, with a NRMSLE for each experiment less than $10 \%$.

The presented model is able to describe the $E$. coli inactivation due to solar water disinfection under mild-heating conditions. This is an important advance in the SODIS process modeling in order to be applied for real field conditions as useful tool for predictive simulation of water disinfection and solar reactor design for SODIS.

\section{Conclusions}

The model of synergistic effect between solar mild heating and solar UV radiation for SODIS presented in this work is a considerable advance for solar water disinfection over the previously reported SODIS model, described for $E$. coli inactivation in clear water. Temperature effect has been for the first time included in a SODIS mechanistic model, to explain the well-recognized syner- gistic effect between water temperature and UV radiation during solar water disinfection. The new model is capable to reproduce successfully the time-profile of viable bacterial concentration over treatment time under different irradiances and temperatures. The synergistic effect between UV\&T was included in the model by means of the temperature dependence of the kinetic constants. The Arrhenius parameters for the photo-generation of $\mathrm{O}_{2}^{--}$by the reduction from oxygen $\left(E a_{2}=3.76 \cdot 10^{3} \mathrm{~J} \mathrm{~mol}^{-1}, A_{2}=7.07\right.$. $10^{21} \mathrm{~cm}^{3}$ Einstein ${ }^{-1} \mathrm{M}^{-1}$ ) and the photo-inactivation of CAT $\left(E a_{9}=5.31 \cdot 10^{4} \mathrm{~J} \mathrm{~mol}^{-1}, \quad A_{9}=3.05 \cdot 10^{16} \mathrm{~cm}^{3}\right.$ Einstein $\left.^{-1}\right) \quad$ were determined. This mechanistic approach of the synergistic effect between solar radiative and thermal effects over bacterial suspensions will permit to use predictive results for real SODIS conditions where irradiance and water temperature change through time, to model new concepts of SODIS reactors and optimize their disinfection performance in terms of final disinfection result and total volume of water treated.

\section{Acknowledgements}

The authors wish to thank the Spanish Ministry of Economy and Competitiveness for financing this research through the collaborative project WATER4FOOD (CTQ2014-54563-C3). The authors wish also to thank the financial support of the European project WATERSPOUTT H2020-Water-5c-2015 (GA 688928).

\section{Appendix}

Derivation of the synergistic SODIS-thermal kinetic model

The model reactions that represent the $E$. coli inactivation due to the synergistic effect between solar radiation and mild-heat are shown in Table 3. It is necessary to notice that the mass balance of viable bacteria has to be proposed for the entire reactor using the reactions Eq. (T3.13) and (T3.14). On the contrary, the rest of the reactions of Table 3 are intracellular reactions and have to be used to solve the mass balances of the internal species for a single cell. According to the isotropic hypothesis, the same internal reactions will occur in all cells without population, time or space preferences. Consequently, the evolution of the concentration of the intracellular species that are involved in the process could be considered the same in all cells. The assumptions to solved the mass balances are: (i) kinetic micro steady-state approximation for concentration of iron $\left(\mathrm{Fe}^{2+}\right.$ and $\left.\mathrm{Fe}^{3+}\right)$ and radicals $\left(\mathrm{O}_{2}^{--}, \mathrm{HO}\right.$ and $\left.\mathrm{HO}_{2}\right)$ inside a bacterial cell and (ii) iron released from cluster due to oxidative stress is neglected.

The iron balances in a single cell are:

$$
\frac{\mathrm{d}\left[\mathrm{Fe}^{2+}\right]}{\mathrm{dt}}=-\frac{\mathrm{d}\left[\mathrm{Fe}^{3+}\right]}{\mathrm{dt}}=-k_{4}(\mathrm{~T})\left[\mathrm{Fe}^{2+}\right]\left[\mathrm{H}_{2} \mathrm{O}_{2}\right]+k_{5}(\mathrm{~T})\left[\mathrm{Fe}^{3+}\right]\left[\mathrm{H}_{2} \mathrm{O}\right] e_{\mathrm{Fe}^{3+}}^{a} \approx 0
$$

$k_{4}(\mathrm{~T})\left[\mathrm{Fe}^{2+}\right]\left[\mathrm{H}_{2} \mathrm{O}_{2}\right]=k_{5}(\mathrm{~T})\left[\mathrm{Fe}^{3+}\right]\left[\mathrm{H}_{2} \mathrm{O}\right] e_{\mathrm{Fe}^{3+}}^{\mathrm{a}}$

The superoxide radical balance in a single cell is:

$$
\begin{aligned}
\frac{\mathrm{d}\left[\mathrm{O}_{2}^{--}\right]}{\mathrm{dt}}= & k_{1}(\mathrm{~T})\left[\mathrm{O}_{2}\right]\left[\mathrm{e}^{-}\right]+k_{2}(\mathrm{~T})\left[\mathrm{O}_{2}\right]\left[\mathrm{e}^{-}\right] e_{\mathrm{NADH}}^{\mathrm{a}}-k_{3}\left[\mathrm{O}_{2}^{--}\right][\mathrm{SOD}] \\
& -k_{12}\left[\mathrm{O}_{2}^{--}\right] \approx 0
\end{aligned}
$$

$\left[\mathrm{O}_{2}^{-}\right]=\frac{\delta_{1} \cdot \exp \left(\frac{-E a_{1}}{R \cdot \mathrm{T}}\right)+\delta_{2} \cdot \exp \left(\frac{-E a_{2}}{R \cdot \mathrm{T}}\right) e_{\mathrm{NADH}}^{\mathrm{a}}}{k_{3}[\mathrm{SOD}]+k_{12}}$

The hydroxyl radical balance in a single cell is:

$$
\begin{aligned}
\frac{\mathrm{d}[\mathrm{HO}]}{\mathrm{dt}}= & -k_{6}\left[\mathrm{H}_{2} \mathrm{O}_{2}\right][\mathrm{HO}]-k_{11}[\mathrm{HO}]+k_{4}(\mathrm{~T})\left[\mathrm{Fe}^{2+}\right]\left[\mathrm{H}_{2} \mathrm{O}_{2}\right] \\
& +k_{5}(\mathrm{~T})\left[\mathrm{Fe}^{3+}\right]\left[\mathrm{H}_{2} \mathrm{O}\right] e_{\mathrm{Fe}^{3+}}^{\mathrm{a}} \approx 0
\end{aligned}
$$


$\left[\mathrm{HO}^{\circ}\right]=\frac{2 \cdot \delta_{3} \cdot \exp \left(\frac{-E a_{4}}{R \cdot \mathrm{T}}\right) \cdot\left[\mathrm{H}_{2} \mathrm{O}_{2}\right]}{k_{6}\left[\mathrm{H}_{2} \mathrm{O}_{2}\right]+k_{11}}$

The hydroperoxyl radical balance in a single cell is:

$$
\begin{aligned}
& \frac{\mathrm{d}\left[\mathrm{HO}_{2}\right]}{\mathrm{dt}}=k_{6}\left[\mathrm{H}_{2} \mathrm{O}_{2}\right][\mathrm{HO}]-k_{7}\left[\mathrm{HO}_{2}\right]^{2} \approx 0 \\
& {\left[\mathrm{HO}_{2}\right]=\sqrt{\frac{k_{6}}{k_{7}}\left[\mathrm{H}_{2} \mathrm{O}_{2}\right][\mathrm{HO}]}}
\end{aligned}
$$

where

$$
\delta_{1}=A_{1}\left[\mathrm{O}_{2}\right]\left[\mathrm{e}^{-}\right], \quad \delta_{2}=A_{2}\left[\mathrm{O}_{2}\right]\left[\mathrm{e}^{-}\right] \text {and } \delta_{3}=A_{4}\left[\mathrm{Fe}^{2+}\right]
$$

The hydrogen peroxide is a compound that cannot be considered in a micro steady state inside the bacterial cell. The rate expression of $\mathrm{H}_{2} \mathrm{O}_{2}$ is obtained by:

$$
\begin{aligned}
\frac{\mathrm{d}\left[\mathrm{H}_{2} \mathrm{O}_{2}\right]}{\mathrm{dt}}= & \frac{1}{2} k_{3}\left[\mathrm{O}_{2}^{-}\right][\mathrm{SOD}]+\frac{1}{2} k_{7}\left[\mathrm{HO}_{2}\right]^{2}-k_{4}(\mathrm{~T})\left[\mathrm{Fe}^{2+}\right]\left[\mathrm{H}_{2} \mathrm{O}_{2}\right] \\
& -k_{6}\left[\mathrm{H}_{2} \mathrm{O}_{2}\right][\mathrm{HO}]-k_{8}\left[\mathrm{H}_{2} \mathrm{O}_{2}\right][\mathrm{CAT}]
\end{aligned}
$$

Introducing the Eqs. (A.4), (A.6) and (A.8) into (A.10) the final expression for hydrogen peroxide concentration over the time is:

$$
\begin{aligned}
\frac{\mathrm{d}\left[\mathrm{H}_{2} \mathrm{O}_{2}\right]}{\mathrm{dt}}= & \frac{1}{2} \cdot \frac{k_{3} \cdot\left[\delta_{1} \cdot \exp \left(\frac{-E a_{1}}{R \cdot \mathrm{T}}\right)+\delta_{2} \cdot \exp \left(\frac{-E a_{2}}{R \cdot \mathrm{T}}\right) \cdot e_{\mathrm{NADH}}^{\mathrm{a}}\right][\mathrm{SOD}]}{k_{3}[\mathrm{SOD}]+k_{12}} \\
& -\frac{\delta_{3} \cdot \exp \left(\frac{-E a_{4}}{R \cdot \mathrm{T}}\right) \cdot k_{6}\left[\mathrm{H}_{2} \mathrm{O}_{2}\right]^{2}}{k_{6}\left[\mathrm{H}_{2} \mathrm{O}_{2}\right]+k_{11}} \\
& -\left(\delta_{3} \cdot \exp \left(\frac{-E a_{4}}{R \cdot \mathrm{T}}\right)+k_{8}[\mathrm{CAT}]\right)\left[\mathrm{H}_{2} \mathrm{O}_{2}\right]
\end{aligned}
$$

The enzymes are inactive over treatment time due to the photon action. Among this, CAT and SOD are species in not steady state:

$$
\begin{aligned}
& \frac{\mathrm{d}[\mathrm{CAT}]}{\mathrm{dt}}=-k_{9}(\mathrm{~T})[\mathrm{CAT}] e_{\mathrm{CAT}}^{\mathrm{a}} \neq 0 \\
& \frac{\mathrm{d}[\mathrm{SOD}]}{\mathrm{dt}}=-k_{10}[\mathrm{SOD}] e_{\mathrm{SOD}}^{\mathrm{a}} \neq 0
\end{aligned}
$$

Introducing the expression of LVRPA of CAT and SOD determined by the Eqs. (9) into (A.12) and (A.13) respectively, the following expressions are obtained:

$$
\begin{aligned}
& \frac{\mathrm{d}[\mathrm{CAT}]}{\mathrm{dt}}=-k_{9} \cdot \overline{\mathrm{\kappa}}_{\mathrm{CAT}}^{*} \cdot \overline{\mathrm{G}} \cdot[\mathrm{CAT}]^{2} \\
& \frac{\mathrm{d}[\mathrm{SOD}]}{\mathrm{dt}}=-k_{10} \cdot \overline{\mathrm{\kappa}}_{\mathrm{SOD}}^{*} \cdot \overline{\mathrm{G}} \cdot[\mathrm{SOD}]^{2}
\end{aligned}
$$

where $\bar{\kappa}_{\mathrm{CAT}}^{*}$ and $\bar{\kappa}_{\mathrm{SOD}}^{*}$ are the specific absorption coefficients of CAT and SOD respectively, and $\bar{G}$ is the incident radiation averaged in the UVA. Integrating Eq. (A.14) and (A.15) from time $t=0$ (initial concentrations of enzymes, $[\mathrm{CAT}]_{0}$ and $[\mathrm{SOD}]_{0}$ ) to an instant time $\mathrm{t}([\mathrm{CAT}]$ and $[\mathrm{SOD}]):[$

$$
\begin{aligned}
& {[\mathrm{CAT}]=\frac{1}{1 /[\mathrm{CAT}]_{0}+k_{9} \cdot \overline{\mathrm{K}}_{\mathrm{CAT}}^{*} \cdot \overline{\mathrm{G}} \cdot \mathrm{t}}} \\
& {[\mathrm{SOD}]=\frac{1}{1 /[\mathrm{SOD}]_{0}+k_{10} \cdot \overline{\mathrm{K}}_{\mathrm{SOD}}^{*} \cdot \overline{\mathrm{G}} \cdot \mathrm{t}}}
\end{aligned}
$$

Finally, the reaction rate of the bacteria inactivation is obtained from the mass balance of the bacteria in the reactor:

$$
\frac{\mathrm{d}\left[\mathrm{B}_{\mathrm{v}}\right]}{\mathrm{dt}}=-k_{13}\left[\mathrm{HO}^{-}\right]\left[\mathrm{O}_{2}^{--}\right]\left[\mathrm{B}_{\mathrm{v}}\right]-k_{14}(\mathrm{~T})\left[\mathrm{B}_{\mathrm{v}}\right]
$$

The rate reaction of the bacteria inactivation $\left(\mathrm{CFU} \mathrm{mL} \mathrm{L}^{-1} \mathrm{~s}^{-1}\right)$ is referred to the reactor volume while the apparent kinetic constant $k_{13}\left(\mathrm{M}^{-2} \mathrm{~s}^{-1}\right)$ is referred to the bacterial cell volume. This is due to viable bacterial reaction rate in water is dependent on the intracellular concentrations of $\mathrm{HO}^{-}$and $\mathrm{O}_{2}^{-}$. Introducing the expression of the radicals concentration and reorganizing, the following expression is obtained:

$$
\begin{aligned}
\frac{\mathrm{d}\left[\mathrm{B}_{\mathrm{v}}\right]}{\mathrm{dt}}= & -\left(\frac{2 \cdot\left[\delta_{1} \cdot \exp \left(\frac{-E a_{1}}{R \cdot \mathrm{T}}\right)+\delta_{2} \cdot \exp \left(\frac{-E a_{2}}{R \cdot \mathrm{T}}\right) e_{\mathrm{NADH}}^{\mathrm{a}}\right] \cdot \delta_{3} \cdot \exp \left(\frac{-E a_{4}}{R \cdot \mathrm{T}}\right) \cdot k_{13} \cdot\left[\mathrm{H}_{2} \mathrm{O}_{2}\right]}{\left(k_{6}\left[\mathrm{H}_{2} \mathrm{O}_{2}\right]+k_{11}\right) \cdot\left(k_{3}[\mathrm{SOD}]+k_{12}\right)}\right. \\
& \left.+A_{14} \cdot \exp \left(\frac{-E a_{14}}{R \cdot \mathrm{T}}\right)\right)\left[\mathrm{B}_{\mathrm{v}}\right]
\end{aligned}
$$

Finally, the model could be solved by the simultaneous solution of the two differential equations, Eq. (A.11) and Eq. (A.19) with the two expressions of enzymes concentrations, Eq. (A.16) and Eq. (A.17).

\section{References}

[1] A. Acra, Y. Karahagopian, Z. Raffoul, R. Dajani, Disinfection of oral rehydration solutions by sunlight, Lancet 2 (1980) 1257-1258.

[2] K.G. McGuigan, R.M. Conroy, H.-J. Mosler, M. du Preez, E. Ubomba-Jaswa, P. Fernandez-Ibañez, Solar water disinfection (SODIS): a review from bench-top to roof-top, J. Hazard. Mater. 235-236 (2012) 29-46.

[3] S. Giannakis, M.I. Polo-López, D. Spuhler, J.A. Sánchez-Pérez, P. FernándezIbáñez, C. Pulgarin, Solar disinfection is an augmentable, in situ-generated photo-Fenton reaction-Part 1: a review of the mechanisms and the fundamental aspects of the process, Appl. Catal. B Environ. 199 (2016) 199223.

[4] M. Castro-Alférez, M.I. Polo-López, J. Marugán, P. Fernández-Ibáñez, Mechanistic model of the Escherichia coli inactivation by solar disinfection based on the photo-generation of internal ROS and the photo-inactivation of enzymes: CAT and SOD, Chem. Eng. J. (2016), in press.

[5] M. Berney, H.-U. Weilenmann, T. Egli, Flow-cytometric study of vital cellular functions in Escherichia coli during solar disinfection (SODIS), Microbiology 152 (2006) 1719-1729.

[6] J.A. Imlay, Cellular defenses against superoxide and hydrogen peroxide, Annu. Rev. Biochem. 77 (2008) 4.1-4.22.

[7] WHO, 2014. WHO International Scheme to Evaluate Household Water Treatment Technologies Harmonized Testing Protocol: Technology NonSpecific.

[8] K.G. McGuigan, T.M. Joyce, R.M. Conroy, J.B. Gillespie, M. Elmore-Meegan, Solar disinfection of drinking water contained in transparent plastic bottles: characterizing the bacterial inactivation process, J. Appl. Microbiol. 84 (1998) $1138-1148$.

[9] E. Ubomba-Jaswa, C. Navntoft, M.I. Polo-López, P. Fernandez-Ibáñez, K.G. McGuigan, Solar disinfection of drinking water (SODIS): an investigation of the effect of UV-A dose on inactivation efficiency, Photochem. Photobiol. Sci. 8 (2009) 587-595.

[10] R.H. Reed, Solar inactivation of faecal bacteria in water: the critical role of oxygen, Lett. Appl. Microbiol. 24 (1997) 276-280.

[11] M. Solic, N. Krstulovic, Separate and combined effects of solar radiation, temperature, salinity, and ph on the survival of faecal coliforms in seawater, Mar. Pollut. Bull. 24 (8) (1992) 411-416.

[12] M. Wegelin, S. Canonica, K. Mechsner, T. Fleischmann, F. Pesaro, A. Metzler, Solar water disinfection: scope of the process and analysis of radiation experiments, J. Water SRT - Aqua 43 (3) (1994) 154-169.

[13] M. Berney, H.-U. Weilenmann, A. Simonetti, T. Egli, Efficacy of solar disinfection of Escherichia coli, Shigella flexneri, Salmonella Typhimurium and Vibrio cholera, J. Appl. Microbiol. 101 (2006) 828-836.

[14] R. Noor, Mechanism to control the cell lysis and the cell survival strategy in stationary phase under heat stress, SpringerPlus 4 (2015) 1-9.

[15] S. Baatout, P. de Boever, M. Mergeay, Temperature-induced changes in bacterial physiology as determined by flow cytometry, Ann. Microbiol. 55 (2005) 73-80.

[16] A.R. Cantemir, A. Raducan, M. Puiu, D. Oance, Kinetics of thermal inactivation of catalase in the presence of additives, Process Biochem. 48 (3) (2013) 471477.

[17] G.V. Buxton, C.L. Greenstock, W.P. Helman, A.B. Ross, Critical review of rate constants for reactions of hydrated electrons, hydrogen atoms and hydroxyl radicals $\left(. \mathrm{OH} / . \mathrm{O}^{-}\right)$in aqueous solution, J. Phys. Chem. Ref. Data 17 (1988) 513886.

[18] J. Farias, E.D. Albizzati, O.M. Alfano, Kinetic study of the photo-Fenton degradation of formic acid. Combined effects of temperature and iron concentration, Catal. Today 144 (2009) 117-123.

[19] H. Gallard, J. De Laat, Kinetic modelling of $\mathrm{Fe}(\mathrm{III}) / \mathrm{H}_{2} \mathrm{O}_{2}$ oxidation reactions in dilute aqueous solution using atrazine as a model organic compound, Water Res. 34 (2000) 3107-3116. 
[20] L.C. Seaver, J.A. Imlay, Alkyl hydroperoxide reductase is the primary scavenger of endogenous hydrogen peroxide in Escherichia coli, J. Bacteriol. 183 (24) (2001) 7173-7181.

[21] J.A. Imlay, Pathways of oxidative damage, Annu. Rev. Microbiol. 57 (2003) $395-418$.

[22] G.H. Rossetti, E.D. Albizzati, O.M. Alfano, Decomposition of Formic Acid in a water solution employing the Photo-Fenton Reaction, Ind. Eng. Chem. Res. 41 2002) 1436-1444.

[23] J. De Laat, H. Gallard, Catalytic decomposition of hydrogen peroxide by Fe(III) in homogeneous aqueous solution: mechanism and kinetic modeling, Environ. Sci. Technol. 33 (1999) 2726-2732.

[24] M.B. Petkar, M.M. Pillai, A.A. Kulkarni, S.H. Bondre, K.R.S.S. Rao, Purification and characterization of superoxide dismutase isolated from sewage isolated E. coli, J. Microb. Biochem. Technol. 5 (4) (2013) 102-106.
[25] M. Zhang, J. Shi, L. Jiang, Modulation of mitochondrial membrane integrity and ROS formation by high temperature in Saccharomyces cerevisiae, Electron. J Biotechnol. 18 (2015) 202-209.

[26] A.S. Hearn, M.E. Stroupe, D.E. Cabelli, J.R. Lepock, J.A. Tainer, H.S. Nick, D.N. Silverman, Kinetic analysis of product inhibition in human manganese superoxide dismutase, Biochemistry 40 (2001) 12051-12058.

[27] M. Castro-Alférez, M.I. Polo-López, P. Fernández-Ibáñez, Intracellular mechanisms of solar water disinfection, Nat. Sci. Rep. 6 (2016) 38145 http://dx.doi.org/10.1038/srep38145.

[28] D. Raes, P. Steduto, T.C. Hsiao E. Fereres, Chapter 2. Users Guide, in AquaCrop Version 4.0, FAO, Land and Water Division, Rome, Italy, 2012. 